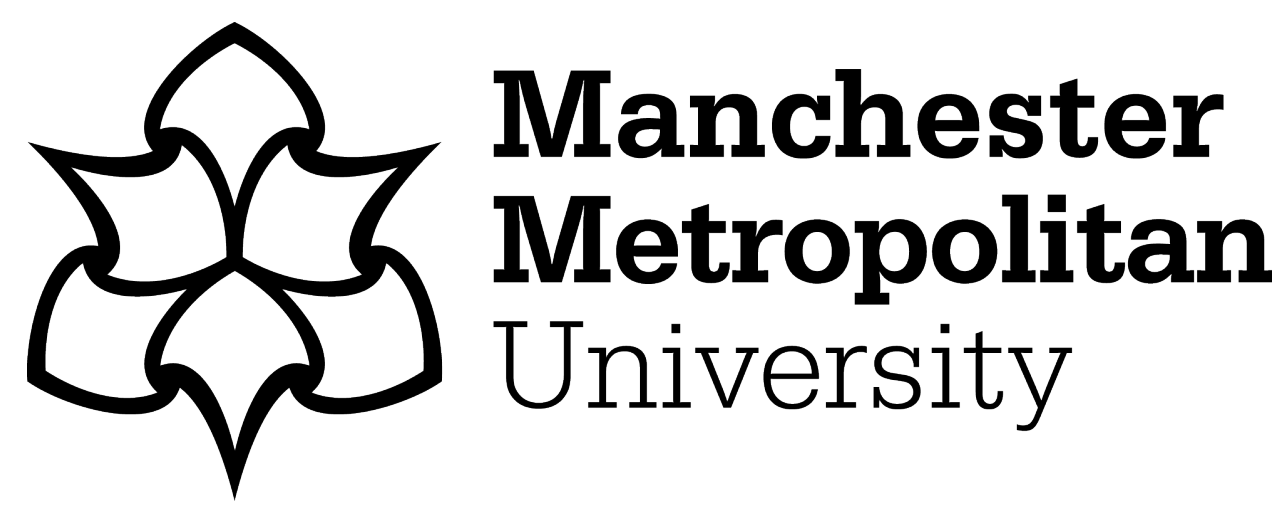

Brophy, Peter (2004) Evaluating the Joint Information Systems Committee's Information Environment: the EDNER and EDNER+ projects. VINE: The Journal of Information and Knowledge Management Systems, 34 (4). pp. 143-147. ISSN 0305-5728

Downloaded from: https://e-space.mmu.ac.uk/1509/

Version: Accepted Version

Publisher: Emerald

DOI: https://doi.org/10.1108/03055720410699928

Usage rights: Creative Commons: Attribution-Noncommercial 4.0

Please cite the published version 


\title{
Evaluating the Joint Information Systems Committee's Information Environment - the EDNER and EDNER+ projects
}

Professor Peter Brophy

Director

CERLIM (the Centre for Research in Library and Information Management) Manchester Metropolitan University, UK

Email: p.brophy@mmu.ac.uk

\begin{abstract}
Since early 2000 the EDNER project has been investigating the impacts of the development of the JISC Information Environment (IE) with particular reference to learning and teaching in higher education.
\end{abstract}

The consortium, led by CERLIM (the Centre for Research in Library and Information Management) at the Manchester Metropolitan University, partnered by CSALT (the Centre for Studies in Advanced Learning Technologies) at Lancaster University, has brought to bear perspectives from both information management and educational research. Using a wide range of methodologies the team has explored the outcomes of a large number of projects funded by the JISC, as well as examining the architecture and rollout of the Information Environment itself. During 2003 to 2004 the scope of the evaluation has been broadened to include all of the JISC development activity in the information environment area and has been extended to the further education sector: this is known as EDNER+. 
In this paper the Director of the project reports on some of the findings of this work concerning the use of the JISC information environment by students, seeking to place this within a broader context by considering how information environments are related to the working environments of their users.

\section{Introduction}

The Joint Information Systems Committee (JISC) works with UK higher and further education (HE and FE) institutions by providing guidance and advice; by funding development programmes in relevant information and communications technology (ICT) applications which support learning, teaching, research and administration; and by providing network and data services to these communities. JISC is also a strategic advisory committee working on behalf of the funding bodies for higher and further education in England, Scotland, Wales and Northern Ireland.

In 1999 funding was made available over three years to improve JISC services with particular emphasis on learning and teaching, and a call for proposals was issued in JISC Circular 5/99 (JISC, 1999) for projects to develop what was then known as Distributed National Electronic Resource (DNER). The DNER was described as:

a managed environment for accessing quality assured information resources on the Internet which are available from many sources. These resources include scholarly journals, monographs, textbooks, abstracts, manuscripts, maps, music scores, still images, geospatial 
images and other kinds of vector and numeric data, as well as moving picture and sound collections (JISC, 1999)

The major foci of this call for proposals were 1) the implementation and development of the DNER itself, 2) enhancements to JISC services to make them more appropriate for learning and teaching, and 3) evaluation studies relating to the first two themes. Projects funded to develop the DNER have been described by Ingram and Grout (2002). The EDNER Project (Formative Evaluation of the DNER, http://www.cerlim.ac.uk/edner) was funded to undertake ongoing evaluation of the developing DNER over the full three years of the JISC 5/99 Learning \& Teaching and Infrastructure Programme period i.e. from 2000 to 2003 . Since its successful completion in 2003 it was awarded a one year extension until July 2004 (EDNER+). The EDNER and EDNER + Projects have been led by the Centre for Research in Library \& Information Management (CERLIM) at the Manchester Metropolitan University with the Centre for Studies in Advanced Learning Technologies (CSALT) at Lancaster University as a partner. This paper reports on some of the work from both the EDNER and EDNER+ Projects.

\section{Methodologies}

Because of its nature as a wide ranging formative evaluation, EDNER/EDNER + has used a wide range of methodologies. Part of the challenge of this kind of investigation has been to manage this mix so as to produce coherent findings. Among the methods used have been: 
- Definition of the evaluation space. It rapidly became apparent that before any kind of evaluative activity could be started we needed to define what exactly was meant by the 'Distributed National Electronic Resource'. In particular, we needed to characterise the ways in which stakeholders anticipated that a 'resource' would impact upon the practice of teaching and the experience of learning. As the concept changed from a 'national resource' to a shared 'Information Environment' we needed to revisit the understanding we had developed. Here, the question was, in what ways does an information environment interact with, engage with, influence and produce change within a learning and teaching space?

- Engagement with the individual projects and with project clusters. We needed to understand 'what made the project tick' and, since we wanted also to influence projects, we wanted to challenge them to surface hidden assumptions. A particularly important workshop, led by CSALT, involved an exercise in surfacing 'implicit theories of change'. In other words we sought to help project teams to face the question of how they assumed changed learning would occur as a result of their project. An alarming number of answers seemed to indicate that there was a widespread assumption that 'improving access' would of itself lead to purposive change. We challenged that assumption.

- Exploration of the information and learning environments of two higher education institutions in depth. We wanted to dig beneath the surface and find out, for example, how JISC services and projects surfaced within institutions. We discovered, to again give an example, that descriptions of services within university web sites were very 
varied, with particularly confused examples in departmental and individual sites. Libraries, it may be noted, provided the beststructured web sites for accessing information resources - a finding that should come as no surprise but perhaps may be greeted by professionals with some relief!

- We undertook targeted surveys of key stakeholders. These ranged from interviews with vice chancellors and principals, with university and college librarians and with subject librarians to questionnaires distributed to various groups of users.

- In-depth experiments were undertaken with groups of undergraduate students, in each case occupying two full days of work, for which the students were paid. This part of EDNER/EDNER+ is described more fully later in this paper.

- We worked with projects to make an assessment of the initial take-up and use of their products. Here we identified some of the key factors inhibiting use, many of which had little or nothing to do with the product/service itself but could be as simple as the lack of online access within the classroom or as complex as finding ways of motivating lecturers to modify the curriculum.

- We undertook documentary and expert analysis in order to identify the validity of assumptions and designs. This was particularly relevant to the analysis of the JISC Information Architecture, which underlies the IE, and which models the complex interactions between IE component systems.

\section{Results}


The EDNER and EDNER+ projects have produced a wealth of reports. Initially many of these were treated as confidential to the JISC, not least because they contained insights gleaned in confidential discussions with projects. However, public versions of virtually all the reports are now available and can be downloaded from the project web site at http://www.cerlim.ac.uk/projects/iee/index.php

In this paper the concentration is on the analysis of student searching behaviour using a quality attributes methodology. This is described below.

\section{Exploring student searching behaviour}

In order to understand better the interaction between students and DNER resources, EDNER carried out some detailed testing of information searching. Using a small group of approximately 40 undergraduate students, the project explored information seeking behaviour with unstructured and structured searches - in the former the students were simply asked to find information on ' $x$ ', while in the latter they were asked to use a particular DNER service cluster to find information. A quality attributes approach was used to guide their assessments (Brophy 2001 see also below). As with other studies (e.g. Zipf (1949), Cmor and Lippold (2001)) it was found that students minimize effort by turning first to Internet search engines, of which by far the most commonly-used was Google, and often appear to engage in 'satisficing' behaviour i.e. they find that readilyavailable information resources, while incomplete and often of doubtful quality, are 'good enough'. This suggests that a challenge for higher and further education will be to ensure that the value of quality-assured resources is appreciated. There are implications also for libraries' work on 
information skills and information literacy. Further there are questions about how 'quality assurance' is defined and operationalised in this context again these are further elaborated below. The student behaviour monitoring exercise was repeated within EDNER+ in relation to the broad JISC Information Environment, although the results of that part of the work are still being analysed.

We were interested in this exercise in the 'quality' of services as judged by a group of their primary users, but we wanted to go beyond a simple approach which would rate services either by overall user satisfaction or by the kind of measures used in information retrieval systems (e.g. recall and precision) which tell us little about the user experience. Having been interested in the approach advocated by Garvin $(1984,1987)$ for some time, we determined to use an adapted quality attributes methodology. The idea behind this is to try to break 'quality' down into different aspects, as perceived by users.

Garvin's methodology has been used by others, notably by Abels, White and Hahn (1997) in assessing web sites. The table below provides a comparison of Garvin's original formulation with that we adopted (Brophy (1998); Griffiths and Brophy (2002); Griffiths (2003)) and that of Abels, White and Hahn. 


\begin{tabular}{|c|c|c|}
\hline GARVIN & $\begin{array}{l}\text { BROPHY and } \\
\text { GRIFFITHS }\end{array}$ & ABELS et al. \\
\hline $\begin{array}{l}\text { Performance, the } \\
\text { primary purpose of } \\
\text { the product or } \\
\text { service and how well } \\
\text { it is achieving that } \\
\text { primary purpose. }\end{array}$ & $\begin{array}{l}\text { Performance, } \\
\text { concerned with } \\
\text { establishing } \\
\text { confirmation that a } \\
\text { service meets its } \\
\text { most basic purpose, } \\
\text { such as making key } \\
\text { information sources } \\
\text { available on demand. }\end{array}$ & $\begin{array}{l}\text { Performance based } \\
\text { on use, including } \\
\text { ease of use, and } \\
\text { content. }\end{array}$ \\
\hline $\begin{array}{l}\text { Features, secondary } \\
\text { characteristics which } \\
\text { add to the service or } \\
\text { product without } \\
\text { being of its essence. }\end{array}$ & $\begin{array}{l}\text { Features: aspects of } \\
\text { the service which } \\
\text { appeal to users but } \\
\text { are beyond the } \\
\text { essential core } \\
\text { performance } \\
\text { attributes. }\end{array}$ & $\begin{array}{l}\text { Features such as } \\
\text { links to other sites } \\
\text { which might better } \\
\text { answer a particular } \\
\text { question. }\end{array}$ \\
\hline $\begin{array}{l}\text { Reliability, the } \\
\text { consistency of the } \\
\text { product or service's } \\
\text { performance in use. }\end{array}$ & $\begin{array}{l}\text { Reliability, which for } \\
\text { information services } \\
\text { would include } \\
\text { availability of the } \\
\text { service. Such } \\
\text { problems as broken } \\
\text { Web links, lack of } \\
\text { reliability and } \\
\text { slowness in speed of } \\
\text { response would be } \\
\text { measured as part of } \\
\text { this attribute. }\end{array}$ & $\begin{array}{l}\text { Reliability, including } \\
\text { both availability and } \\
\text { currency/accuracy of } \\
\text { information provided. }\end{array}$ \\
\hline
\end{tabular}




\begin{tabular}{|c|c|c|}
\hline GARVIN & $\begin{array}{l}\text { BROPHY and } \\
\text { GRIFFITHS }\end{array}$ & ABELS et al. \\
\hline $\begin{array}{l}\text { Conformance, } \\
\text { whether or not the } \\
\text { product or service } \\
\text { meets the agreed } \\
\text { standard, which may } \\
\text { be internally or } \\
\text { externally generated. }\end{array}$ & $\begin{array}{l}\text { Conformance: } \\
\text { whether the service } \\
\text { meets the agreed } \\
\text { standard, including } \\
\text { conformance } \\
\text { questions around the } \\
\text { utilisation of } \\
\text { standards and } \\
\text { protocols such as } \\
\text { XML, RDF, Dublin } \\
\text { Core, OAI, Z39.50 } \\
\text { etc. }\end{array}$ & (Not defined) \\
\hline $\begin{array}{l}\text { Durability, the } \\
\text { amount of use the } \\
\text { product or service } \\
\text { can provide before it } \\
\text { deteriorates to a } \\
\text { point where it needs } \\
\text { replacement. }\end{array}$ & $\begin{array}{l}\text { Durability, related to } \\
\text { the sustainability of } \\
\text { the information or } \\
\text { library service over a } \\
\text { period of time. }\end{array}$ & (Not defined) \\
\hline & $\begin{array}{l}\text { Currency of } \\
\text { information, that is, } \\
\text { how up to date the } \\
\text { information provided } \\
\text { is when it is } \\
\text { retrieved. }\end{array}$ & $\begin{array}{l}\text { (Treated as part of } \\
\text { "Reliability") }\end{array}$ \\
\hline
\end{tabular}




\begin{tabular}{|c|c|c|}
\hline GARVIN & $\begin{array}{l}\text { BROPHY and } \\
\text { GRIFFITHS }\end{array}$ & ABELS et al. \\
\hline $\begin{array}{l}\text { Serviceability, how } \\
\text { easy it is to repair a } \\
\text { product or correct a } \\
\text { service when it goes } \\
\text { wrong, including the } \\
\text { level of } \\
\text { inconvenience } \\
\text { experienced by the } \\
\text { customer. }\end{array}$ & $\begin{array}{l}\text { Serviceability, which } \\
\text { may translate to the } \\
\text { level of help } \\
\text { available to users } \\
\text { during, for example, } \\
\text { information retrieval, } \\
\text { or otherwise at the } \\
\text { point of need. The } \\
\text { availability of } \\
\text { instructions and } \\
\text { prompts throughout } \\
\text { an online service, } \\
\text { context sensitive } \\
\text { help and the } \\
\text { usefulness of that } \\
\text { help could be } \\
\text { measured in order to } \\
\text { assess performance } \\
\text { under this attribute. }\end{array}$ & $\begin{array}{l}\text { Serviceability } \\
\text { concerned with the } \\
\text { handling of } \\
\text { complaints and } \\
\text { conflicts, with the } \\
\text { aim of creating a } \\
\text { happy and satisfied } \\
\text { customer. }\end{array}$ \\
\hline $\begin{array}{l}\text { Aesthetics, the } \\
\text { appearance of the } \\
\text { product or service. }\end{array}$ & $\begin{array}{l}\text { Aesthetics and } \\
\text { Image, related to the } \\
\text { appearance and } \\
\text { attractiveness of the } \\
\text { service in the } \\
\text { judgement of the } \\
\text { user. }\end{array}$ & $\begin{array}{l}\text { Aesthetics, } \\
\text { concerned with } \\
\text { visual attractiveness }\end{array}$ \\
\hline
\end{tabular}




\begin{tabular}{|c|c|c|}
\hline GARVIN & $\begin{array}{l}\text { BROPHY and } \\
\text { GRIFFITHS }\end{array}$ & ABELS et al. \\
\hline $\begin{array}{l}\text { Perceived quality, in } \\
\text { essence the } \\
\text { reputation of the } \\
\text { product or service } \\
\text { among the } \\
\text { population, } \\
\text { especially those with } \\
\text { whom the potential } \\
\text { customer comes into } \\
\text { contact. }\end{array}$ & $\begin{array}{l}\text { Perceived Quality: } \\
\text { the user's view of } \\
\text { the service as a } \\
\text { whole and the } \\
\text { information retrieved } \\
\text { from it. It may be } \\
\text { useful to measure } \\
\text { perceptions both } \\
\text { before and after a } \\
\text { service is used. }\end{array}$ & $\begin{array}{l}\text { Reputation, related } \\
\text { to past experiences } \\
\text { of the site. }\end{array}$ \\
\hline & $\begin{array}{l}\text { Usability, which is } \\
\text { particularly relevant } \\
\text { to electronic services } \\
\text { and includes issues } \\
\text { of accessibility for } \\
\text { those with a } \\
\text { disability. }\end{array}$ & $\begin{array}{l}\text { Structure, which is } \\
\text { concerned with how } \\
\text { information is } \\
\text { structured within the } \\
\text { web site's } \\
\text { presentation. }\end{array}$ \\
\hline & & $\begin{array}{l}\text { Storage capability, } \\
\text { which is concerned } \\
\text { with whether all } \\
\text { required information } \\
\text { can be stored in } \\
\text { order to answer } \\
\text { queries which may, } \\
\text { for example, require } \\
\text { an historical analysis. }\end{array}$ \\
\hline
\end{tabular}




\begin{tabular}{|c|c|c|}
\hline \multirow[t]{5}{*}{ GARVIN } & $\begin{array}{l}\text { BROPHY and } \\
\text { GRIFFITHS }\end{array}$ & ABELS et al. \\
\hline & & $\begin{array}{l}\text { Security and system } \\
\text { integrity, including } \\
\text { the handling of } \\
\text { payment (e.g. credit } \\
\text { card) data. }\end{array}$ \\
\hline & & $\begin{array}{l}\text { Trust, whether users } \\
\text { are wiling to disclose } \\
\text { personal information. } \\
\text { Closely linked to } \\
\text { "Security and system } \\
\text { integrity". }\end{array}$ \\
\hline & & $\begin{array}{l}\text { Responsiveness, } \\
\text { which includes } \\
\text { courtesy and } \\
\text { willingness to be } \\
\text { flexible (for example } \\
\text { with a cancelled } \\
\text { order). }\end{array}$ \\
\hline & & $\begin{array}{l}\text { Product/service } \\
\text { differentiation and } \\
\text { customization, which } \\
\text { asks what is unique } \\
\text { about this particular } \\
\text { web site, not least to } \\
\text { differentiate it from } \\
\text { its competitors. }\end{array}$ \\
\hline
\end{tabular}




\begin{tabular}{|c|c|c|}
\hline GARVIN & $\begin{array}{l}\text { BROPHY and } \\
\text { GRIFFITHS }\end{array}$ & ABELS et al. \\
\hline & & $\begin{array}{l}\text { Web store policies, } \\
\text { which relates to the } \\
\text { customer-orientation } \\
\text { of policies and might } \\
\text { involve a comparison } \\
\text { with a high street } \\
\text { store. }\end{array}$ \\
\hline & & $\begin{array}{l}\text { Assurance, } \\
\text { concerned with the } \\
\text { creation of good } \\
\text { customer } \\
\text { experiences through } \\
\text { the knowledgability } \\
\text { and courtesy of staff. }\end{array}$ \\
\hline & & $\begin{array}{l}\text { Empathy, which may } \\
\text { be expressed } \\
\text { through the } \\
\text { availability of } \\
\text { individualised } \\
\text { personal attention. }\end{array}$ \\
\hline
\end{tabular}

The relationship of these approaches to other methods of assessing quality in library and information services has been addressed elsewhere (Brophy, 2004).

In the exercises with students we used eight attributes:

- Performance

- Features 
- Reliability

- Currency

- Serviceability

- Aesthetics

- Perceived quality

- Usability

Conformance and durability were not tested as they would be outwith the experience and competence of end users to judge.

We reported on our findings from the first iteration of this exercise (related to the 5/99 projects with three control services) in 2002 (Brophy, Fisher, Griffiths and Markland, 2002); at the time of writing this paper a second, similar exercise (related to the IE) was still being analysed.

The full results of this work can be accessed in the report referred to above, but here we present a sample of two results to illustrate our findings and the kinds of conclusions (or inferences) that might be drawn from them.

\begin{tabular}{|c|c|c|c|c|c|c|c|c|c|}
\hline & $\begin{array}{l}\frac{\alpha}{d} \\
\frac{1}{d} \\
\frac{N}{U} \\
\frac{D}{U}\end{array}$ & $\begin{array}{l}\infty \\
\frac{1}{d} \\
\stackrel{n}{\Delta} \\
\frac{D}{U}\end{array}$ & 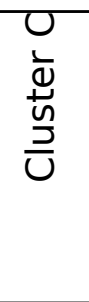 & 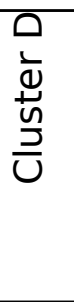 & 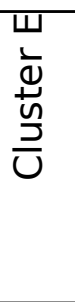 & $\begin{array}{l}\frac{\square}{\bar{Q}} \\
\stackrel{\underline{N}}{\underline{D}} \\
\frac{D}{U}\end{array}$ & $\begin{array}{l}\frac{0}{O} \\
O \\
0 \\
0\end{array}$ & 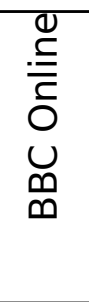 & 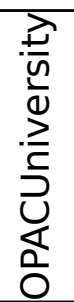 \\
\hline $\begin{array}{l}\text { Performanc } \\
\text { e }\end{array}$ & 92 & 56 & 100 & 80 & 40 & 89 & 93 & 100 & 52 \\
\hline Aesthetics & 80 & 40 & 96 & 62 & 56 & 89 & 82 & 85 & 67 \\
\hline $\begin{array}{l}\text { Overall } \\
\text { Satisfactio } \\
n\end{array}$ & 88 & 32 & 96 & 58 & 29 & 73 & 89 & 96 & 63 \\
\hline
\end{tabular}


Table 1 shows the mean rating given to each of the tested services by the students for the two attributes 'performance' and 'aesthetics', together with the mean overall rating. While there is a clear correlation between the results for each service there are some interesting differences. Cluster $B$, for example, was given a low overall rating of $32 \%$, but scored $56 \%$ for performance i.e. its ability to retrieve items. Cluster E had a similar overall rating but its aesthetics and performance scores were reversed. Cluster $\mathrm{F}$ scored highly for both performance and aesthetics, but its lower overall satisfaction rating suggests other factors were not so highly rated.

We noted that, of the control services, both Google and BBC Online scored highly for all attributes. The University OPAC was somewhat less highly rated.

\section{Conclusions}

The use of quality attributes approaches can provide clues as to what it is about a service which is creating dissatisfaction among the users. Coupled with other findings about satisficing behaviours, the findings are suggestive of some of the key areas which need to be given attention. They also support a finding from this and other work in EDNER/EDNER + , namely that to students the Internet search engines in general and Google in particular represent a benchmark of 'good'. Having found that use of bibliographic services is uniformly low among undergraduate students, and that the use of OPACs is variable, we conclude that IE service developers will have to work very hard to produce services which gain acceptance among this group of users. Since the IE includes further education students among its target user groups, it will be critical to address the full range of attributes 
against the needs of this, as well as the higher education group, in future service design.

\section{Acknowledgement}

I would like to express my thanks to all the staff of the EDNER and EDNER+ projects, who contributed as a real team to the many different exercises in which we engaged. 


\section{References}

Abels, E.G., White, M.D. and Hahn, K. (1997) Identifying user-based criteria for Web pages. Internet Research: Electronic Networking Applications and Policy, 7(4), 252-62.

Brophy P, Fisher S, Griffiths J. R. and Markland M. (2001) EDNER: Formative Evaluation of the Distributed National Electronic Resource: DNER Service evaluation (Deliverable MDA 2, EDNER Project). Manchester: CERLIM (The Centre for Research in Library \& Information Management). Available at http://www.cerlim.ac.uk/projects/iee/index.php Brophy, P. (1998) It may be electronic but is it any good? Measuring the performance of electronic services. Robots to Knowbots: the wider automation agenda. Proceedings of the Victorian Association for Library Automation 9th Biennial Conference, January 28-30 1998. Melbourne, Australia: VALA, 217-230. <http://www.vala.org.au/valaweb/num511.pdf> Brophy, P. (2004) The Quality of Libraries. In Die effective Bibliothek.

München: K. G. Saur. pp. 30-46

Cmor, D. and Lippold, K. (2001). Surfing vs. searching: the Web as a research tool. Presented at the $21^{\text {st }}$ Annual Conference of the Society for Teaching and Learning in Higher Education. [-Online] http://www.mun.ca/library/research_help/qeii/stlhe/

Garvin, D. A. (1984) What Does "Product Quality" Really Mean? Sloan Management Review, 25-45.

Garvin, D. A. (1987) Competing on the Eight Dimensions of Quality. Harvard Business Review, November-December, 108-109. 
Griffiths, J.R. (2003) Evaluation of the JISC Information Environment: student perceptions of services. Information Research. http://informationr.net/ir/84/paper160.html

Griffiths, J.R. and Brophy, P. (2002) Student searching behaviour in the JISC Information Environment. Ariadne, 33.

<http://www.ariadne.ac.uk/issue33/edner/intro.html>

Zipf, G. (1949). Human Behaviour and the Principle of Least Effort. Reading MA: Addison-Wesley. 